OPEN ACCESS

Edited by:

Sarah Burke,

University Medical Center Groningen,

Netherlands

Reviewed by:

Chantal Wiepjes,

Amsterdam University Medical Center,

Netherlands

Nienke Nota,

VU University Medical Center,

Netherlands

*Correspondence:

Mireia Mora

mporta@clinic.cat

Specialty section:

This article was submitted to Neuroendocrine Science,

a section of the journa

Frontiers in Endocrinology

Received: 31 May 2021 Accepted: 02 September 2021 Published: 30 September 2021

Citation:

Aranda G, Halperin I, Gomez-Gil E, Hanzu FA, Seguí N, Guillamon A and Mora M (2021) Cardiovascular Risk

Associated With Gender

Affirming Hormone Therapy in

Transgender Population.

Front. Endocrinol. 12:718200. doi: 10.3389/fendo.2021.718200

\section{Cardiovascular Risk Associated With Gender Affirming Hormone Therapy in Transgender Population}

\author{
Gloria Aranda ${ }^{1}$, Irene Halperin ${ }^{1,2}$, Esther Gomez-Gil ${ }^{3}$, Felicia A. Hanzu ${ }^{1,2}$, Núria Segui ${ }^{2}$, \\ Antonio Guillamon ${ }^{4}$ and Mireia Mora ${ }^{1,2 *}$ \\ ${ }^{1}$ Group of Endocrine Disorders, Institut d'Investigacions Biomèdiques August Pi I Sunyer- Hospital Clinic, Barcelona, Spain, \\ 2 Endocrinology Department, Hospital Clinic, Barcelona, Spain, ${ }^{3}$ Psychiatry Department, Hospital Clínic, Barcelona, Spain, \\ ${ }^{4}$ Departamento de Psicobiologia, Universidad Nacional de Educación a Distancia (UNED), Madrid, Spain
}

Transgender men and women represent about $0.6-1.1 \% \%$ of the general population. Gender affirming hormone therapy (GAHT) helps ameliorate gender dysphoria and promote well-being. However, these treatments' cardiovascular (CV) effects are difficult to evaluate due to the limited number of extensive longitudinal studies focused on CV outcomes in this population. Furthermore, these studies are mainly observational and difficult to interpret due to a variety of hormone regimens and observation periods, together with possible bias by confounding factors (comorbidities, estrogen types, smoking, alcohol abuse, HIV infection). In addition, the introduction of GAHT at increasingly earlier ages, even before the full development of the secondary sexual characteristics, could lead to long-term changes in CV risk compared to current data.

This review examines the impact of GAHT in the transgender population on CV outcomes and surrogate markers of $\mathrm{CV}$ health. Furthermore, we review available data on changes in DNA methylation or RNA transcription induced by GAHT that may translate into changes in metabolic parameters that could increase CV risk.

Keywords: transgender women, transgender men, transgender population, gender affirming hormone therapy, cardiovascular risk

\section{INTRODUCTION}

Transgender people represent about $0.6-1.1 \%$ of the general population, 0.7 and $1.1 \%$ of people assigned male at birth, and 0.6 and $0.8 \%$ of people assigned female at birth, as described in an European study of T'Sjoen et al. (1). Gender affirming hormone therapy (GAHT) helps ameliorate gender dysphoria by changing the physical appearance in accordance with gender identity and expression and promote well-being (2). However, this therapy's cardiovascular (CV) effects are difficult to evaluate because most of the studies are observational and can have a possible bias due to confounding factors such as comorbidities, variety of hormone regimens, smoking, alcohol abuse or HIV infection. Cardiovascular disease (CVD) is the main cause of death for transgender people undergoing GAHT, although suicide is still the leader of all-cause mortality (3). However, for 
transgender women, the risk of death from CVD is 3-fold higher than for ciswomen and cismen and has been associated with the use of ethinyl estradiol (EE) $(2,4)$. Moreover, the introduction of GAHT at increasing earlier ages may lead to changes in CV risk compared to current data.

This review examines the impact of GAHT in transgender people on CV outcomes and surrogate markers of CV health. Furthermore, we review available data on changes in DNA methylation or RNA transcription induced by GAHT that may translate into changes in metabolic parameters that could increase $\mathrm{CV}$ risk.

\section{METHODS}

We performed a review to evaluate $\mathrm{CV}$ health in transgender population. We searched in PubMed/MEDLINE databases for articles with this topic, we included articles published until April 2021, and we limited the search to English language articles. The Keywords were transgender, transgender men, transgender women, hormone therapy, GAHT, estrogen, antiandrogen, progesterone, testosterone, cardiovascular disease, and cardiovascular risk factors.

We included retrospective, observational, cohort, crosssectional studies, population survey of transgender individuals, with a minimum population size of 100 individuals and a followup of 1 year, with GAHT regardless of doses or gender affirming surgery in which $\mathrm{CV}$ outcomes (thromboembolism, myocardial infarction, stroke) and surrogate markers of $\mathrm{CV}$ risk have been assessed.

\section{FEMINIZING HORMONE THERAPY IN TRANSGENDER WOMEN}

Current evidence from Europe and America suggests that GAHT initiated and monitored under medical supervision is associated with very low rates of adverse events $(5,6)$. However, factors associated with a higher risk of thromboembolic conditions, such as smoking, obesity, and sedentary lifestyle, should be evaluated in transgender women prior to initiating GAHT and modified if possible. In certain cases, using the transdermal route and anticoagulant treatment should be considered to prevent thromboembolisms. In addition, other diseases such as coronary artery and cerebrovascular disease, hormone-sensitive cancers, hyperprolactinemia, hypertriglyceridemia, and cholelithiasis should be assessed, as these conditions can be exacerbated by estrogen and may be considered relative contraindications for GAHT $(7,8)$. Moreover, information related to fertility preservation should be provided, and options for preservation should be discussed and offered before starting the medication.

\section{Types of Hormonal Therapy in Transgender Women}

There are two main classes of medications used in transgender women: estrogenic therapies and androgen-lowering hormone therapies. Table 1 shows the most frequent regimens used nowadays.

In relation to estrogenic therapies, $\mathrm{EE}$ is a synthetic estrogen widely used in Europe prior to 2003 (9). However, given recent safety concerns about its prothrombotic potential and its possible role in $\mathrm{CV}$ disease, most clinicians have now switched to oral, cutaneous, or IM estradiol valerate (7). Studies that compare the long-term safety and effectiveness among the different formulations of estradiol are lacking. The Endocrine Society guidelines recommend titrating the doses to serum estradiol levels at $100-200 \mathrm{pg} / \mathrm{ml}(367.1-734.3 \mathrm{pmol} / \mathrm{l})(7)$.

In general, androgen-lowering therapies are required to reduce testosterone levels into the female range. One of the most prescribed androgen-lowering medications is oral cyproterone acetate (CPA) $(5,10)$. CPA is an androgen receptor blocker but also has some progesterone-like activity (11). Due to reports of increased incidence of meningiomas (12-14), association with depression, and increased

TABLE 1 | Gender affirming hormone therapy.

\begin{tabular}{|c|c|c|c|}
\hline Hormone & Route & Doses & Considerations \\
\hline Estradiol valerate & Oral & $2-6 m g / d$ & $<45$ years \\
\hline \multirow[t]{2}{*}{ Estradiol valerate or cypionate } & placed every $3-5 d$ & 5 - 30mg IM every $2 \mathrm{wk}$ & \\
\hline & Parenteral & 2 - 10mg IM every wk & \\
\hline \multicolumn{4}{|l|}{ Anti-androgens } \\
\hline Spironolactone & Oral & $100-300 \mathrm{mg} / \mathrm{d}$ & Preferred in USA \\
\hline & & $11.25 \mathrm{mg} / 3$ monthly & of antiandrogens \\
\hline \multicolumn{4}{|l|}{ Transgender males } \\
\hline \multicolumn{4}{|l|}{ Testosterone } \\
\hline Testosterone enanthate or cypionate & Parenteral & $100-200 \mathrm{mg}$ every $2-4$ wk or $50 \%$ per $1-2 \mathrm{wk}$ & \\
\hline Testosterone undecanoate & Parenteral & $1000 \mathrm{mg}$ every $12 \mathrm{wk}$ & \\
\hline Testosterone gel $1.6 \%$ & Transdermal & $50-100 \mathrm{mg} / \mathrm{d}$ & \\
\hline
\end{tabular}

SC, subcutaneous; WK, week. 
risk of hyperprolactinemia with $\mathrm{CPA}$ use, the maximum recommended dose is $25 \mathrm{mg}$ daily $(15,16)$. The study by Kuijpers et al. has observed that the 10mg dose of CPA is as effective as higher doses but with fewer side effects (17). In UK, Italy, and Netherlands, transgender women are now treated with GnRH agonist (GnRHa) to lower testosterone levels (18). GnRHa substitutes the pulsatile physiological release of GnRH by a continued release of the GnRHa administrated and inhibits the secretion of FSH/LH from the pituitary to the testicle/ovary. Gosereline and leuprolide have been used instead of CPA to reduce testosterone levels and lower adverse reactions (7). Spironolactone lowers testosterone synthesis and action at the androgen receptor and is also an antagonist of the mineralocorticoid receptor and potassiumsparing diuretic. Flutamide also has antiandrogenic effects, but it is not recommended $(7,18,19)$.

Progesterone therapies such as medroxyprogesterone have been used to reduce testosterone concentrations in transgender women (19). Some may ask for progesterone to enhance breast development; however, clinical evidence does not support this effect (20). Furthermore, there are concerns regarding the potential increased risk of thromboembolism and stroke found in cisgender women taking progesterone $(21,22)$.

Finasteride therapy ( $5 \alpha$-reductase inhibitor) has effectively improved hair loss in transgender women with androgenic alopecia without significant side effects. Nevertheless, the routine use of $5 \alpha$-reductase inhibitors has been limited over previous concerns of long-term sexual dysfunction and depression reported in cisgender men $(23,24)$.

\section{Physical Changes in Transgender Women}

The aim of GAHT in transgender women is to induce feminine and reduce masculine physical traits. The development of breast tissue is one of the most expected changes in transgender women and is associated with improvement in body discomfort score (25). However, less than $20 \%$ of transgender women reach Tanner breast stage 4 to 5 after 24 months of hormone therapy; therefore, mammoplasty is often requested. Several studies show that a plateau is achieved within the first 6-9 months of treatment (26-28). Recent data suggests that sustained breast development was observed during a period of three years of follow-up with a more lateral and caudal position compared to ciswomen (28). Testicular volume decreases $\sim 60 \%$ after 24 months of GAHT is also observed, as well as reduction of erections and ejaculation (25). An increase in body weight was associated with an increase in body fat, specifically in the gynoid regions, and a reduction in lean body mass $(25,29-31)$. Facial hair diminished and the Ferriman-Gallwey scores improved after two years of GAHT, as well as the hair loss pattern (25). Voice changes are seldom observed; therefore, transgender women will have to look for voice therapy or phonosurgery $(32,33)$.

\section{Metabolic Changes in Transgender Women}

The metabolic effects of estrogen therapy are focused on liver function alterations and lipid parameters. Hepatic lipase activity decreases by $64 \%$ and lipoprotein lipase by $23 \%$. Hepatic lipase decreases HDL-cholesterol (HDL-c) levels and increases the formation of small, dense LDL (LDL-c) highly atherogenic. Reduction of hepatic lipase levels with estrogen may reduce the formation of LDL-c (34). However, the use of estrogen therapy in transgender women showed no statistically significant difference in total cholesterol, serum LDL-c or HDL-c, but an increase in plasma triglyceride levels after 24 months was found (35). Conflicting data seem to show unmodified or reduced insulin sensitivity, with unaltered fasting glucose and stable or increased blood pressure (34). Estrogen therapy in transgender women has been associated with reduced plasma homocysteine levels, independently of the route of administration $(36,37)$. The impact of estrogens on prothrombotic status remains unclear. While some studies with EE in combination with CPA, but not with transdermal estradiol, show an increase in C-reactive protein (CRP) and decreased tissue plasminogen activator; other studies have shown no effect on CRP $(38,39)$.

\section{Cardiovascular Outcomes in Transgender Women}

Data in transgender women receiving estrogen therapy are limited to observational and cohort studies. However, retrospective studies have shown a higher incidence of thromboembolic events in transgender women with $\mathrm{EE}$ and CPA compared to a similar reference group of the population (40) and using equine estrogens compared to estrogen valerate or EE when mammoplasty was performed (16). Table 2 shows the studies that evaluated CV outcomes and mortality associated with GAHT.

A systematic review and meta-analysis of CV outcomes in transgender people reported few cases of myocardial infarction (MI), stroke, or venous thrombosis; however, the incidence was higher in transgender women compared to transgender men $(35,40)$.

In 2018, a nationwide US survey was distributed across 22 states and included questions about the transgender condition; $0.6 \%$ of those surveyed identified as transgender people. The study found that transgender women reported higher MI than cisgender women (OR 2.9; 95\% CI, 1.6 to 5.3 ; $\mathrm{p}<0.001$ ) but with no differences when compared to cisgender men (44).

In addition, a survey conducted by the Centers for Disease Control and Prevention, with 1.8 million participants, also observed that all transgender individuals receiving GAHT had significantly higher rates of MI compared to their cisgender counterparts; after adjusting for CVD risk factors, transgender women had more than a two-fold increased risk in MI compared to cisgender women. Transgender women had no significant difference in MI risk compared to cisgender men (45).

A Dutch study of 2517 transgender women using estrogen followed for an average of 9 years found twice as many strokes and MIs as in cisgender women and almost twice as many strokes and no difference in MIs compared to cisgender men; also a five-fold and four-fold increase risk in thromboembolic events compared to both ciswomen and cismen, respectively (46). 
TABLE 2 | Cardiovascular outcomes.

\begin{tabular}{|c|c|c|c|c|c|c|c|c|}
\hline Author & Country/Year & $\mathbf{n}$ & Study & GAHT & $\begin{array}{l}\text { Follow- } \\
\text { up }\end{array}$ & $\begin{array}{l}\text { Time of } \\
\text { GAHT }\end{array}$ & CV Outcomes (n) & Mortality \\
\hline Asscheman $\mathbf{H}$ et al. (40) & Netherlands 1989 & $\begin{array}{l}303 \mathrm{TW} \\
122 \mathrm{TM}\end{array}$ & Retrospective study & $\begin{array}{l}\text { EE 100ug+ CPA } 100 \mathrm{mg} \\
\text { Long-acting testosterone ester } 250 \mathrm{mg} / 2 \mathrm{wk} \\
\text { Oral testosterone undecanoate } 120-160 \mathrm{mg} / \mathrm{d}\end{array}$ & $\begin{array}{l}14 \\
\text { years }\end{array}$ & $\begin{array}{l}\text { TW 4.4yr } \\
\text { TM 3.6yr }\end{array}$ & $\begin{array}{l}\text { VT/PE (29) TW } \\
\text { Weight } \uparrow>10 \% \\
\text { MI (2) TW }\end{array}$ & No CV mortality \\
\hline $\begin{array}{l}\text { Van Kesteren PJ et al. } \\
(41)\end{array}$ & Netherlands 1997 & $\begin{array}{l}816 \mathrm{TW} \\
293 \mathrm{TM}\end{array}$ & Retrospective study & $\begin{array}{l}\text { Oral estrogens + anti-androgens. } \\
\text { Transdermal estradiol }\end{array}$ & & & $\begin{array}{l}\text { VT/PE TW } \\
\text { No morbidity in TM }\end{array}$ & $\begin{array}{l}\text { Total mortality was no } \\
\text { higher than in the } \\
\text { general population }\end{array}$ \\
\hline Asscheman $\mathbf{H}$ et al. (4) & Netherlands 2011 & $\begin{array}{l}966 \mathrm{TW} \\
365 \mathrm{TM}\end{array}$ & Cohort study & $\begin{array}{l}\text { EE or conjugated estrogens (until 1989). } \\
\text { Transdermal E2 } \\
\text { Estradiol valerate } 2-4 \mathrm{mg} / \mathrm{d} \\
\text { CPA } 100 \mathrm{mg} / \mathrm{d} \\
\text { Spironolactone } 100-200 \mathrm{mg} / \mathrm{d} \text {. } \\
\text { Testosterone ester IM } 250 \mathrm{mg} / 2 \mathrm{wk} \\
\text { Oral testosterone undecanoate } 160-240 \mathrm{mg} / \mathrm{d} \\
\text { Transdermal testosterone } 50 \mathrm{mg} / \mathrm{d} \\
\text { Lynestrenol (uterine bleeding persisted) }\end{array}$ & $\begin{array}{l}18.5 \\
\text { years }\end{array}$ & $\begin{array}{l}\text { TW 19.4yr } \\
\text { TM 18.8yr }\end{array}$ & $\begin{array}{l}\text { Ischemic heart disease } \\
18 \text { TW } \\
1 \text { TM } \\
\text { Cerebrovascular } \\
\text { accidents } \\
5 \text { TW } \\
0 \text { TM }\end{array}$ & $\begin{array}{l}\text { SMR TW } 1.51 \text { (1.47- } \\
1.55) \\
\text { SMR TM } 1.12 \text { (0.89- } \\
1.59)\end{array}$ \\
\hline Dhejne $\mathbf{C}$ et al. (3) & Sweden 2011 & $\begin{array}{l}191 \mathrm{TW} \\
133 \mathrm{TM}\end{array}$ & Cohort study & Not available & $\begin{array}{l}30 \\
\text { years }\end{array}$ & & Not available & HR 2.5 (1.2-5.3) \\
\hline Wierckx K et al. (42) & Belgium 2012 & $\begin{array}{l}50 \mathrm{TW} \\
50 \mathrm{TM}\end{array}$ & Cross-sectional study & $\begin{array}{l}\text { Estrogen + CPA } \\
\text { Testosterone }\end{array}$ & $\begin{array}{l}10 \\
\text { years }\end{array}$ & $\begin{array}{l}\text { TW 6.3yr } \\
\text { TM 8.7yr TM }\end{array}$ & $\begin{array}{l}\text { Only TW } \\
\text { TV/PE (4) } \\
\text { TIA (1) } \\
\text { Ml (1) }\end{array}$ & Not available \\
\hline Wierckx K et al. (43) & Belgium 2013 & $\begin{array}{l}214 \mathrm{TW} \\
138 \mathrm{TM}\end{array}$ & Case-control study & $\begin{array}{l}\text { Transdermal estradiol gel/patch } \\
\text { Estradiol valerate } 2 \mathrm{mg} \\
\text { EE 50mcg } \\
\text { Oral contraceptive } \\
\text { Testosterone ester IM 2-3wk } \\
\text { Transdermal testosterone } 50 \mathrm{mg} / \mathrm{d} \\
\text { Oral testosterone undecanoate }\end{array}$ & $\begin{array}{l}22 \\
\text { years }\end{array}$ & $\begin{array}{l}\text { TW 7.7yr } \\
\text { TM 9.7yr }\end{array}$ & $\begin{array}{l}\text { TW } \\
\text { VT/PE } \\
\text { Ml } \\
\text { TIA/CVD } \\
\text { T2DM } \\
\text { TM } \\
\text { VT/PE } \\
\text { T2DM }\end{array}$ & $\begin{array}{l}9 \mathrm{TW} \\
1 \mathrm{TM}\end{array}$ \\
\hline Wierckx K et al. (5) & Belgium 2014 & $\begin{array}{l}53 \mathrm{TW} \\
53 \mathrm{TM}\end{array}$ & $\begin{array}{l}\text { Prospective multicenter } \\
\text { study }\end{array}$ & $\begin{array}{l}<45 \mathrm{yr} \\
50 \mathrm{mg} \mathrm{CPA}+4 \mathrm{mg} \text { valerate estradiol } \\
>45 \mathrm{yr} \\
50 \mathrm{mg} \mathrm{CPA}+100 \mathrm{ug} / 24 \mathrm{hs} \text { transdermal 17B } \\
\text { estradiol } \\
\text { IM Testosterone undecanoate every } 3 \text { months }\end{array}$ & $\begin{array}{l}12 \\
\text { months }\end{array}$ & 12 months & $\begin{array}{l}\text { No severe adverse } \\
\text { events }\end{array}$ & $\begin{array}{l}\text { No deaths were } \\
\text { observed }\end{array}$ \\
\hline
\end{tabular}




\begin{tabular}{|c|c|c|c|c|c|c|c|c|}
\hline Author & Country/Year & $\mathrm{n}$ & Study & GAHT & $\begin{array}{l}\text { Follow- } \\
\text { up }\end{array}$ & $\begin{array}{l}\text { Time of } \\
\text { GAHT }\end{array}$ & CV Outcomes (n) & Mortality \\
\hline Nokoff $\mathbf{N}$ et al. (44) & USA 2018 & $\begin{array}{l}369 \text { TW } \\
239 \text { TM } \\
156 \\
\text { GNC }\end{array}$ & $\begin{array}{l}\text { Secondary Data analysis } \\
\text { based on } 2015 \text { Behaviors } \\
\text { Risk Factor Surveillance } \\
\text { System Survey (CDC) } \\
\text { Cross-sectional study }\end{array}$ & Not available & - & - & $\begin{array}{l}\text { TW } \\
\text { HTA 29.2\% } \\
\text { Ml 5.5\% } \\
\text { Angina or CHD 3.5\% } \\
\text { Stroke 2.6\% } \\
\text { TM } \\
\text { HTA 25.2\% } \\
\text { Ml 2\% } \\
\text { Angina or CHD 3.1\% } \\
\text { Stroke 2.3\% } \\
\text { No differences in GNC } \\
\text { between cisgender } \\
\text { men and women }\end{array}$ & \\
\hline Alzahrani T et al. (45) & USA 2019 & $\begin{array}{l}1842439 \\
1267 \text { TM } \\
1788 \text { TW }\end{array}$ & $\begin{array}{l}\text { Combined data of } \\
\text { Behavioral Risk Factor } \\
\text { Surveillance } \\
\text { System (BRFSS) (CDC) } \\
\text { Cross-sectional study }\end{array}$ & Not available & - & - & $\begin{array}{l}\text { Ml } \\
\text { TW } \\
\text { OR } 2.56 \text { vs CIS W } \\
\text { No increase vs CIS M } \\
\text { TM } \\
\text { OR } 2.53 \text { vs CIS M } \\
\text { OR } 4.90 \text { vs CIS W }\end{array}$ & Not available \\
\hline Nota NM et al. (46) & Netherlands 2019 & $\begin{array}{l}2517 \text { TW } \\
1358 \text { TM }\end{array}$ & Retrospective study & Not available & $\begin{array}{l}43 \\
\text { years }\end{array}$ & $\begin{array}{l}\text { TW: 22.83yr } \\
\text { TM: 11.03yr }\end{array}$ & $\begin{array}{l}\text { TW } \\
\text { Stroke (29) } \\
\text { MI (30) } \\
\text { VT (73) } \\
\text { TM } \\
\text { Stroke (6) } \\
\text { MI (11) } \\
\text { VT (2) }\end{array}$ & Not available \\
\hline Scheres JLL et al. (47) & $\begin{array}{l}\text { European Network } \\
\text { for the Investigation } \\
\text { of Gender } \\
\text { Incongruence } \\
\text { (ENIGI) } 2021\end{array}$ & $\begin{array}{l}92 \text { TW } \\
100 \text { TM }\end{array}$ & $\begin{array}{l}\text { Longitudinal study } \\
\text { Baseline and } 12 \text { months } \\
\text { after GAHT }\end{array}$ & $\begin{array}{l}\text { Oral estrogen } \\
\text { Transdermal estrogen } \\
\text { Anti-androgen therapy + estrogen oral } \\
\text { Anti-androgen monotherapy } \\
\text { Transdermal testosterone } \\
\text { IM testosterone }\end{array}$ & $\begin{array}{l}12 \\
\text { months }\end{array}$ & 12 months & $\begin{array}{l}\text { TW } \\
\uparrow F I X \\
\uparrow F X I \\
\downarrow p C \\
\downarrow \text { activated protein C } \\
\text { resistance }\end{array}$ & Not available \\
\hline
\end{tabular}

CHD, Coronary heart disease; CIS M, cisgender men; CIS W, cisgender women; CPA, Cyproterone acetate; CV, cardiovascular; EE, Ethinyl Estradiol; FIX, Factor IX; FXI, Factor XI; GAHT, gender affirming hormone therapy; HR, Hazard ratio; MI, Myocardial Infarction; PC, C protein; TIA, Transient ischemic attack; TM, Transgender men;TW, Transgender women; VT/PE, venous thrombosis, embolism pulmonary; $\uparrow:$ increased; $\downarrow:$ decreased. 


\section{MASCULINIZING HORMONE THERAPY IN TRANSGENDER MEN}

Masculinizing GAHT in transgender men favors male secondary sex characteristics and minimizes feminine traits. Transgender men must be informed of the necessity of lifelong therapy with testosterone, its possibilities, risks, consequences, and limitations. Information related to options for the preservation of fertility should be provided before starting GAHT (7). Pregnancy contraindicates testosterone therapy, and relative contraindications include severe hypertension, sleep apnea, and polycythemia. Erythrocytosis, sleep apnea, and congestive heart failure can be exacerbated by testosterone therapy (7).

\section{Types of Hormonal Therapy in Transgender Men}

The main GAHT used to induce virilization is testosterone. Different testosterone formulations may be available depending on geographical location (Table 1). Most prescribed are injectable testosterone esters. Both parenteral and transdermal administration of testosterone are equally effective to achieve masculinization and serum testosterone values in the range of $300-1000 \mathrm{ng} / \mathrm{dl}(10.4-37.4 \mathrm{nmol} / \mathrm{l})$ in transgender men. Serum testosterone levels in injectable formulations are measured between administrations, although clinicians may choose to measure serum testosterone $24 \mathrm{hs}$ after injection and prior to the next dose (7).

More recently, the subcutaneous administration of testosterone was shown to be effective and preferred by transgender men at a median dosage of $75 \mathrm{mg}$ weekly (48). In Pelusi et al. study, the effects of three different testosterone formulations (gel, cypionate, and undecanoate) were evaluated at baseline. After 12 months of treatment, no differences were found regarding short-term safety, compliance, body composition, or metabolic parameters (49).

If menstrual bleeding does not stop after initiation of testosterone, a progestational agent, such as oral lynestrenol at 5 to $10 \mathrm{mg}$ daily or medroxyprogesterone at 5 to $10 \mathrm{mg}$, might be considered $(7,50)$.

\section{Physical Changes in Transgender Men}

Menses discontinuation, clitoris enlargement, and lower-pitched voice are some of the changes aimed by transgender men $(7,51$, 52). In addition, therapy will enhance a more masculine musculature, body shape with an increase in body weight, a decrease in body fat, and an increase in lean mass as well as grip strength (51-55). Testosterone therapy has been associated with increases in the Ferryman-Gallwey hirsutism scores. However, after 12 months, facial and abdominal hair do not reach diameters found in cisgender males. An increase in acne and alopecia is often observed as some of the side effects $(51,52,54)$.

\section{Metabolic Changes in Transgender Men}

Lipid parameters are adversely modified by testosterone therapy in transgender men. A recent meta-analysis of the available data demonstrated no change in total cholesterol or LDL-c. Still, there was a minor increase in triglyceride and a decrease in plasma HDL-c levels, both of which are pro-atherogenic $(55,56)$. Another meta-analysis showed a progressive change in lipid parameters over 24 months with higher triglycerides levels compared with baseline; statistically significant serum LDL-c increase and HDL-c decrease were also observed, with no statistically significant differences in total serum cholesterol level (56). Testosterone therapy has no effect on fasting glucose, fasting insulin, or glucose utilization. However, transgender men were found to have decreased adiponectin, which is associated with insulin resistance and higher CV risk (34). Regarding blood pressure, the results of various studies are contradictory (57). Testosterone therapy increases plasma homocysteine levels in transgender men, which could have a negative impact on CV risk. After one year of hormonal treatment, transgender men presented increased homocysteine and leucocytes levels, with an increase in mean maximum carotid intimal media thickness $(36,54)$.

\section{Cardiovascular Outcomes in Transgender Men}

Present evidence regarding testosterone therapy and CV disease risk in transgender men is controversial. Several studies have observed that despite the negative effects of testosterone therapy on surrogate risks factors of $\mathrm{CV}$ disease, these do not translate into a significant effect on CV outcomes (Table 2). Furthermore, no elevated rates of $\mathrm{CV}$ deaths have been observed when compared with cisgender men and women at short and medium follow-up $(30,35,40,56)$.

In a cross-sectional study of 50 transgender men on testosterone therapy during an average of 10 years, no subject had experienced MI, stroke, or deep venous thrombosis (57). In a similar case-control study, 138 transgender men on testosterone therapy for an average of 7.4 years showed low $\mathrm{CV}$ morbidity. In transgender men, MI was higher when compared to cisgender women, but there was no difference when compared to cisgender men. After adjustment for $\mathrm{CV}$ risk factors, however, the study demonstrated that transgender men had an increased risk for MI compared to both cisgender populations. This study emphasizes the importance of additional CV risk factors such as smoking, reduced exercise, diabetes, and non-Caucasian ethnic origin, all of which were seen in higher numbers in the transgender population $(35,43)$. Similar data in the Dutch analysis of 1358 transgender men using testosterone followed for an average of 8 years, which found three times more MIs as in cisgender women with no differences compared to cisgender men and no differences in stroke compared to cisgender women or men (46).

There have been reports of a possible link between testosterone replacement therapy use and increased venous thromboembolism risk; however, these studies were criticized for including data on avascular necrosis of the femoral head, which are not classically viewed as venous thromboembolic events. Extensive epidemiological studies have demonstrated that there is no link between testosterone therapy and thromboembolism risk $(46,58)$. 


\section{HORMONAL TREATMENT IN ADOLESCENTS}

The treatment in adolescents is generally based on two phases: the first phase consists of suppressing the gonadal axis once puberty has commenced (Tanner 2-3); The second phase is the introduction of the GAHT. Gonadal suppression is generally performed with GnRHa such as gosereline, leuprolide, triptoreline, and histrelin; it provides the adolescent and its family with the time and the space to explore the gender identity before the treatments starts which can imply irreversible changes. Suppression also improves the anxiety for developing the secondary sexual characters associated with the gender assigned at birth $(7,59)$. Scarce information is available concerning the metabolic effects of suppressive treatment; however, a decrease in height velocity in both transgender girls and boys is observed, as well as an increase in body mass index in comparison to the gender assigned at birth, with an increase in fat body mass and a decrease in lean body mass during the first year, that is stabilized afterwards. No effects on lipid or carbohydrate metabolism have been described (59). However, long-term CV effects are still unknown, so a healthy lifestyle and no smoking are encouraged. The effects of GnRHa on bone structure are still in debate. Data suggest that bone mineral density is preserved, but z-score decreases (more in transgender girls than boys) with improvement after GAHT introduction (60). Some side effects must be monitored, such as flushing, headache, mood changes, and hypertension (triptoreline) or intracranial hypertension (rare and associated to leuprolide). Other less effective alternatives used as a suppressive treatment are $\mathrm{CPA}$ in transgender girls or medroxyprogesterone to suppress menses in transgender boys (59-63).

GAHT introduction is generally recommended around the age of 16, although it can be considered around the ages of 14-16, even though there are very few published studies of being administered between the ages of 13.5 and 14 (7). There are two treatment regimens. In the case that GnRHa was introduced early in pubertal development, the puberty of the desired gender is induced by slow increasing doses of testosterone or estradiol, that are modified every six months. In the case that GnRHa began late in puberty, the suppression lasts about 3-6 months and GAHT begins at higher doses, with a faster increase to achieve maintenance dose $(7,62)$.

Since the long-term effects of both suppressive and GAHT treatment are uncertain, adolescents must be encouraged to adopt a healthy lifestyle, increase exercise, avoid tobacco, and keep regular check-ups with the endocrinologist for the monitorization of liver and renal function, lipids, and glucose.

\section{MOLECULAR EFFECTS OF GENDER AFFIRMING HORMONE THERAPY}

Basic research has found Androgen Receptors (AR) and Estrogen Receptors (ERs) in endothelial cells, suggesting that masculinizing and feminizing hormones have a direct impact on the vascular endothelium. Testosterone and estrogen bind to these receptors producing an increase in transcription of atheroprotective genes and a downregulation of pro-atherogenic genes, which could be associated with a decrease in CV risk (64). In the work carried out by our group, we observed an increase in the ER methylation pattern in transgender men after 12 months of GAHT, an increase in AR methylation pattern in transgender women after 12 months of estrogenic treatment. Regarding the expression analysis, AR expression was significantly decreased in transgender men. AR, ER methylation were correlated with anthropometric, metabolic, and hormonal parameters, supporting that GAHT is associated with epigenetic changes that might affect the response to treatment with sex steroids (65). More recent data has also shown that GAHT modified the methylation pattern of ER, more similar to their gender (66). Therefore, research in methylation and expression of AR and ER may help to understand the different effects of GAHT in physical, metabolic, and CV outcomes in transgender people.

\section{DISCUSSION}

Several studies have been published concerning the metabolic effects of GAHT in both transgender women and men. However, data for metabolic effects are often contradictory and inconclusive. The main reasons are the observational and retrospective nature of studies, including populations with diverse hormonal regimens without medical supervision; most of them include $\mathrm{EE}$ at high doses in transgender women; the influence of possible bias by confounding factors (comorbidities, smoking, alcohol abuse, or HIV infection) (2-5, $9,35,40,46)$.

In transgender women, recent regimens have excluded EE and suse oral and transdermal estradiol associated to CPA or other androgen-lowering agents under endocrinological control. Unfortunately, prospective data are still limited, and it is uncertain if these changes may improve $\mathrm{CV}$ and thromboembolic risk (2-7, $35,40,45)$. However, recent data suggest a higher risk of MI compared with ciswomen with no differences in comparison to cismen (44-46).

In transgender men, previous data suggest a lower risk of $\mathrm{CV}$ events in comparison to birth-assigned males, probably due to testosterone introduction at later ages and the possible protective effect of endogen estrogens before GAHT (2-7, 35, 40, 44-46). A prospective study performed by our group showed an impairment of lipid profile and an increase of homocysteine and leucocytes count, as well as a higher mean-maximum common intima-media thickness after 12 months of GATH (55). Recent data suggest a higher risk of $\mathrm{MI}$ in transgender men in comparison with ciswomen.

The introduction of GAHT at increasingly earlier ages, even before the full development of the secondary sexual traits, could lead to long-term changes in $\mathrm{CV}$ risk compared to current data and bring it closer or higher to the known risk of the identified gender (59-63). Future research is essential to find out this risk. 
Moreover, non-binary transgender population may yearn for a more personalized treatment with a partial suppression of the traits associated with the gender assigned at birth and the development of some of the traits of the other gender. No clear regimens have been established, and no information is available concerning the effects on CV risk. Hence, future research in this group is necessary to ascertain their risk of CV illness.

In conclusion, future research should join forces to obtain data from prospective controlled studies, including larger samples. Therefore, studies should consider the introduction of GATH at progressively younger ages as well as the voice of non-binary transgender population in order to improve the knowledge of the $\mathrm{CV}$ effects of hormone therapy in these situations.

\section{REFERENCES}

1. T'Sjoen G, Arcelus J, Gooren L, Klink DT, Tangpricha V. Endocrinology of Transgender Medicine. Endocr Rev (2019) 40(1):97-117. doi: 10.1210/ er.2018-00011

2. Dutra E, Lee J, Torbati T, Garcia M, Merz CNB, Shufelt C. Cardiovascular Implications of Gender-Affirming Hormone Treatment in the Transgender Population. Maturitas (2019) 129:45-9. doi: 10.1016/j.maturitas.2019.08.010

3. Dhejne C, Lichtenstein P, Boman $M$, Johansson ALV, Lângtröm N, Landén M. Long-Term Follow-Up of Transsexual Persons Undergoing Sex Reassignment Surgery: Cohort Study in Sweden. PLoS One (2011) 6(2): e16885-5. doi: 10.1371/journal.pone.0016885

4. Asscheman H, Giltay E, Megens JA, Pim de Ronde W, von Trotsenburg M, Gooren LJ. A Long-Term Follow-Up Study of Mortality in Transsexuals Receiving Treatment With Cross-Sex Hormones. Eur J Endocrinol (2011) 164 (4):635-42. doi: 10.1530/EJE-10-1038

5. Wierckx K, Van Caenegem E, Schreiner T, Haraldsen I, Fisher AD, Toye K, et al. Cross-Sex Hormone Therapy in Trans Persons Is Safe and Effective at Short-Time Follow-Up: Results From the European Network for the Investigation of Gender Incongruence. J Sex Med (2014) 11(8):1999-2011. doi: $10.1111 /$ jsm. 12571

6. Weinand JD, Safer JD. Hormone Therapy in Transgender Adults Is Safe With Provider Supervision; A Review of Hormone Therapy Sequelae for Transgender Individuals. J Clin Transl Endocrinol (2015) 2(2):55-60. doi: $10.1016 /$ j.jcte.2015.02.003

7. Hembree WC, Cohen-Kettenis PT, Gooren LJ, Hannema SE, Meyer WJ, Murad $\mathrm{MH}$, et al. Endocrine Treatment of Gender-Dysphoric/Gender Incongruent Persons: An Endocrine Society Clinical Practice Guideline. J Clin Endocrinol Metab (2017) 102(11):3869-3903. doi: 10.1210/jc.2017-01658

8. Bell EJ, Lutsey PL, Basu S, Cushman M, Heckbert SR, Lloy-Jones DM, et al. Lifetime Risk of Venous Thromboembolism in Two Cohort Studies. Am J Med (2016) 129(3):339.e26. doi: 10.1016/j.amjmed.2015.10.014

9. Asscheman H, T'Sjoen G, Lemaire A, Mas M, Meriggiola MC, Mueller A, et al. Venous Thromboembolism as a Complication of Cross-Sex Hormone Treatment of Male-to-Female Transsexual Subjects: A Review. Andrologia (2014) 46(7):791-5. doi: 10.1111/and.12150

10. Dekler MJ, Wierckx K, Van Caenegem E, Klaver M, Kreukels BP, Elaut E, et al. A European Network for the Investigation of Gender Incongruence: Endocrine Part. J Sex Med (2016) 13(6):994-9. doi: 10.1016/j.jsxm. 2016.03.371

11. Gava G, Cerpolini S, Martelli V, Battista G, Seracchioli R, Meriggiola MC. Cyproterone Acetate vs Leuprolide Acetate in Combination With Transdermal Oestradiol in Transwomen: A Comparison of Safety and Effectiveness. Clin Endocrinol (Oxf) (2016) 85(2):239-46. doi: 10.1111/ cen. 13050

12. Mancini J, Rotilio A, Coati I, Seracchioli R, Martelli V, Meriggiola MC. Presentation of a Meningioma in a Transwoman After Nine Years of Cyproterone Acetate and Estradiol Intake: Case Report and Literature Review. Gynecol Endocrinol (2018) 34(6):456-9. doi: 10.3174/ajnr.A1978

\section{AUTHOR CONTRIBUTIONS}

Conceived and designed the review: MM. Writing the manuscript: GA, MM, IH and NS. Revised the manuscript and contributed significantly to the intellectual value of the paper: $\mathrm{IH}$, FH, EG-G, and AG. All authors contributed to the article and approved the submitted version.

\section{FUNDING}

This review has been possible with the economical help of the project PGC2018-094919-B-C21.

13. Gil M, Oliva B, Timoner J, Maciá MA, Bryant V, de Abajo FJ. Risk of Meningioma Among Users of High Doses of Cyproterone Acetate as Compared With the General Population: Evidence From a PopulationBased Cohort Study. Br J Clin Pharmacol (2011) 72(6):965-8. doi: 10.1210/ jc.2012-2030

14. Gonçalves AM, Page P, Domingo V, Méder JF, Oppenheim C. Abrut Regression of a Meningioma After Discontinuation of Cyproterone Treatment. AJNR Am J Neuroradiol (2010) 31(8):1504-5. doi: 10.3174/ ajnr.A1978

15. Defreyne J, Nota N, Pereira C, Schreiner T, Fisher AD, den Heijer M, et al. Transient Elevated Serum Prolactin in Trans Women Is Caused by Cyproterone Acetate Treatment. LGBT Health (2017) 4(5):328-36. doi: 10.1016/S2213-8587(17)30068-2

16. Seal LJ, Franklin S, Richards C, Shishkareva A, Sinclaire C, Barret J. Predictive Markers for Mammoplasty and a Comparison of Side Effect Profiles in Transwomen Taking Various Hormonal Regimens. J Clin Endocrinol Metab (2012) 97(12):4422-8. doi: 10.4158/EP12170.OR

17. Kuijpers SME, Wiepjes CM, Conemans EB, Fisher AD, T'Sjoen G, den Heijer M. Toward a Lowest Effective Dose of Cyproterone Acetate in Trans Women: Results From the ENIGI Study. J Clin Endocrinol Metab (2021) 14:dgab427. doi: $10.1111 /$ jsm. 12487

18. Mamoojee Y, Seal LJ, Quinton R. Transgender Hormone Therapy: Understanding International Variation in Practice. Lancet Diabetes Endocrinol (2017) 5(4):243-6. doi: 10.1016/S2213-8587(17)30068-2

19. Leinung MC, Urizar MF, Patel N, Sood SC. Endocrine Treatment of Transsexual Persons: Extensive Personal Experience. Endocr Pract (2013) 19(4):664-50. doi: 10.1016/j.thromres.2010.08.010

20. Wierckx K, Gooren LJ, T'Sjoen G. Clinical Review: Breast Development in Trans Women Receiving Cross-Sex Hormones. J Sex Med (2014) 11(5):12407. doi: $10.1111 /$ ced.13184

21. Manson JE, Itsia J, Johnson KC, Rossouw JE, Assaf AR, Lasser NL, et al. Women's Health Initiative Investigators. Estrogens Plus Progestin and the Risk of Coronary Heart Disease. N Engl J Med (2003) 349(6):523-34. doi: 10.1089/trgh.2016.0022

22. Barsoum MK, Heit JA, Ashrani AA, Leibson CL, Petterson TM, Bailey KR. Is Progestin an Independent Risk Factor for Incident Venous Thromboembolism? A Population-Based Case Control Study. Thromb Res (2010) 126(5):373-8. doi: 10.1210/jc.2016-1276

23. Moreno-Arrones OM, Becerra A, Vano-Galvan S. Therapeutic Experience With Oral Finasteride for Androgenetic Alopecia in Female-to-Male Transgender Patients. Clin Exp Dermatol (2017) 42(7):743-8. doi: 10.1210/ clinem/dgaa841

24. Stevenson MO, Wixon N, Safer JD. Scalp Hair Regrowth in Hormone-Treated Transgender Woman. Transgend Health (2016) 1(1):202-4. doi: 10.1530/EJE17-0496

25. Fisher AD, Castellini G, Ristori J, Casale H, Cassioli E, Sensi C, et al. Cross-Sex Hormone Treatment and Psychobiological Changes in Transsexual Persons: Two-Year Follow-Up Data. J Clin Endocrinol Metab (2016) 101(11):4260-9. doi: 10.1002/lary.26716 
26. Meyer WJ III, Webb A, Stuart CA, Finkelstein JW, Lawrence B, Walker PA. Physical and Hormonal Evaluation of Transsexual Patients: A Longitudinal Study. Arch Sex Behav (1986) 15(2):121-38. doi: 10.1002/lary.26110

27. De Blok CJM, Klaver M, Wiepjes CM, Nota NH, Heijboer AC, Fisher AD, et al. Breast Development in Transwomen After 1 Year of Cross-Sex Hormone Therapy: Results of a Prospective Multicenter Study. J Clin Endocrinol Metab (2018) 103(2):532-8. doi: 10.1046/j.1365-2265.2003.01753.x

28. De Blok CJM, Dijkman B, Wiepjes C, Staphorius A, Timmermmans F, Smit J, et al. Sustained Breast Development and Breast Anthropometric Changes in 3 Years of Gender Affirming Hormone Treatment. J Clin Endocrinol Metab (2021) 106(2):e782-90. doi: 10.1210/jc.2017-01643

29. Klaver M, Dekker MJHJ, de Mutser R, Twisk JWR, den Heijer M. Cross-Sex Hormone Therapy in Transgender Persons Affects Total Body Weight, Body Fat and Lean Body Mass: A Meta-Analysis. Andrologia (2017) 49(5):e12660. doi: 10.1210/jcem.83.2.4574

30. Quiros C, Patrascioiu I, Mora M, Aranda GB, Hanzu FA, Godás T, et al. Effects of Cross-Sex Hormone Treatment on Cardiovascular Risk Factors in Transsexual Individuals. Experience in a Specialized Unit in Catalonia. Endocrinol Nutri (2015) 62(5):210-6. doi: 10.1016/S0021-9150(03)00090-X

31. Klaver M, de BloK CJM, Wiepjes CM, Nota NM, Dekker MJHS, de Mutsert R, et al. Changes in Regional Body Fat, Lean Body Mass and Body Shape in Trans Persons Using Cross-Sex Hormonal Therapy: Results From a Multicenter Prospective Study. Eur J Endocrinol (2018) 178(2):163-71. doi: 10.1055/s0037-1614026

32. Bultynck C, Pas C, Defreyne J, Cosyns M, den Heijer M, T'Sjoen G. SelfPerception of Voice in Transgender Persons During Cross-Sex Hormone Therapy. Laryngoscope (2017) 127(12):2796-804. doi: 10.1161/01.ATV.20.5.1396

33. Meister J, Kühn H, Shehata-Dieler W, Hagen R, Kleinasser N. Perceptual Analysis of the Male-to-Female Transgender Voice After Glottoplasty - the Telephone Test. Laryngoscope (2017) 127(4):875-81. doi: 10.1002/lary.26110

34. Elbers JM, Giltay EJ, Teerlink T, Scheffer P, Asscheman H, Seidell J, et al. Effects of Sex Steroids on Components of the Insulin Resistance Syndrome in Transsexual Subjects. Clin Endocrinol (Endocrinol) (2003) 58:562-71. doi: 10.1046/j.1365-2265.1997.2601068.x

35. Maraka S, Sing Ospina N, Rodriguez-Gutierrez R, Davidge-Pitts C, Nippoldt T, Prokop L, et al. Sex Steroids and Cardiovascular Outcomes in Transgender Individuals: A Systematic Review and Meta-Analysis. J Clin Endocrinol Metab (2017) 102:3914-23. doi: 10.1111/j.1743-6109.2012.02876.x

36. Giltay EJ, Hoogeveen EK, Elbers JM, Gooren LJ, Asscheman H, Stehouwer CD. Effects of Sex Steroids on Plasma Total Homocysteine Levels: A Study in Transsexual Males and Females. J Clin Endocrinol Metab (1998) 83:550-3. doi: 10.1530/EJE-13-0493

37. Giltay EJ, Verhoef P, Gooren LJ, Geleijnse JM, Schouten EG. Oral and Transdermal Estrogens Both Lower Plasma Total Homocysteine in Male-toFemale Transsexuals. Atherosclerosis (2003) 168:139-46. doi: 10.1210/js.2017-00465

38. Giltay EJ, Gooren LJ, Emeis JJ, Kooistrta T, Stehouwer CD. Oral Ethinyl Estradiol, But Not Transdermal 17beta-Estradiol, Increases Plasma CReactive Proteins Levels in Men. Thromb Haemost (2000) 84:359-60. doi: 10.1161/CIRCOUTCOMES.119.005597

39. Giltay EJ, Gooren LJ, Emeis JJ, Kooistra T, Stenhouwer CD. Oral, But Not Transdermal, Administration of Estrogens Levels in Humans Without Affecting Endothelials Synthesis. Arterioscler Thromb Vasc Biol (2000) 20:1396-403. doi: 10.1161/01.atv.20.5.1396

40. Asscheman H. Gooren LJ, Eklund PL. Mortality and Morbidity in Transsexual Patients With Cross-Gender Hormone Treatment. Metabolism (1989) 38 (9):869-73. doi: $10.1111 /$ th. 15256

41. Van Kesteren PJ, Asscheman H, Megens JA, Gooren LJ. Mortality and Morbidity in Transsexual Subjects Treated With Cross-Sex Hormones. Clin Endocrinol (Oxf) (1997) 47(3):337-42. doi: 10.1210/jc.2017-00359

42. Wierckx K, Mueller S, Weyers S, Van Caenegem E, Roef G, Heylens G, et al. Long-Term Evaluation of Cross-Sex Hormone Treatment in Transsexual Persons. J Sex Med (2012) 9(10):2641-51. doi: 10.1111/jsm.12698

43. Wierckx K, Elaut E, Declercq E, Heylens G, De Cuypere G, Taes Y, et al. Prevalence of Cardiovascular Disease and Cancer During Cross-Sex Hormone Therapy in a Large Cohort of Trans Persons: A Case-Control Study. Eur J Endocrinol (2013) 169(4):471-8. doi: 10.1210/jc.2007-1809

44. Nokoff NJ, Scarbro S, Juarez-Colunga E, Moreau KL, Kempe A. Health and Cardiometabolic Disease in Transgender Adults in the United States:
Behavioral Risk Factor Surveillance System 2015. J Endocr Soc (2018) 2 (4):349-60. doi: 10.1097/MED.0000000000000064

45. Alzahrani T, Nguyen T, Ryan A, Dwairy A, McCaffey J, Yunus R, et al. Cardiovascular Disease Risk Factor and Myocardial Infarction in the Transgender Population. Cir Cardiovasc Qual Outcomes (2019) 12(4): e005597. doi: 10.1016/S2213-8587(16)00036-X

46. Nota Nienke M, Wiepjes CM, de Blok C, Gooren LJ, Kreukels BPC, den Heijer M. Ocurrence of Acute Cardiovascular Events in Transgender Individuals Receiving Hormone Therapy. Circulation (2019) 139(11):1461-2. doi: 10.1016/j.endinu.2018.11.004

47. Scheres LJJ, Selier NLD, Nota NM, van Diemen JJK, Cannegieter SC, den Heijer M. Effect of Gender-Affirming Hormone Use on Coagulation Profiles in Transmen and Transwomen. J Thromb Haemost (2021) 19(4):1029-37. doi: $10.1111 /$ jth. 15256

48. Sprat DI, Stewart II, Savage C, Craig W, Spack NP, Chandler DW, et al. Subcutaneous Injection of Testosterone Is an Effective and Preferred Alternative to Intramuscular Injection: Demonstration in Female-to-Male Transgender Patients. J Clin Endocrinol Metab (2017) 102(7):2349-55. doi: 10.1111/j.1365-2265.2009.03632.x

49. Pelusi C, Costantino A, Martelli A, Lambertini M, Bazzocchi A, Ponti F, et al. Effects of Three Different Testosterone Formulations in Female-to-Male Transsexual Persons. J Sex Med (2014) 11(12):3002-11. doi: 10.1111/andr.12382

50. Gooren LJ, Giltay EJ, Bunck MC. Long-Term Treatment of Transsexuals With Cross-Sex Hormones: Extensive Personal Experience. J Clin Endocrinol Metab (2008) 93(1):19-25. doi: 10.1210/jc.2007-1809

51. Gooren LJ. Management of Female-to-Male Transgender Persons: Medical and Surgical Management Life Expectancy. Curr Opin Endocrinol Diabetes Obes (2014) 21(3):233-8. doi: 10.1016/j.thromres.2018.10.023

52. Irwig MS. Testosterone Therapy for Transgender Men. Lancet Diabetes Endocrinol (2017) 5(4):301-11. doi: 10.1016/S2213-8587(16)00036-X

53. Gooren LJ. Clinical Practice. Care of Transexual Persons. N Engl J Med (2011) 364(13):1251-7. doi: 10.1210/clinem/dgaa604

54. Meriggiola MC, Gava G. Endocrine Care of Trans-People Part I. A Review of Cross-Sex Hormonal Treatments, Outcomes and Adverse Effects in Transmen. Clin Endocrinol (Oxf) (2015) 83(5):597-606. doi: 10.1007/s10508-020-01660-8

55. Aranda G, Mora M, Hanzu FA, Vera J, Ortega E, Halperin I. Effects of Sex Steroids on Cardiovascular Risk Profile in Transgender Men Under Gender Affirming Hormone Therapy. Endocrinol Diabetes Nutr (2019) 66(6):385-92. doi: 10.1016/j.cpcardiol.2018.09.003

56. Elamin MB, García MZ, Murad MH, Erwin PJ, Montori VM. Effect of Sex Steroid Use on Cardiovascular Risk in Transsexual Individuals: A Systematic Review and Meta-Analysis. Clin Endocrinol (Oxf) (2010) 72(1):1-10. doi: 10.1016/j.jsbmb.2017.05.010

57. Velho I, Fighera TM, Ziegelmann PK. Effects of Testosterone Therapy on BMI, Blood Pressure, and Laboratory Profile of Transgender Men: A Systematic Review. Andrology (2017) 5:881-8. doi: 10.1016/j.jsxm.2020.05.027

58. Houghton DE, Alsawas M, Barrionuevo P, Tello M, Farah W, Beuschel B, et al. Testosterone Therapy and Venous Thromboembolism: A Systematic Review and Meta-Analysis. Thromb Res (2018) 172:94-103. doi: 10.1080/09513590. 2017.1395839

59. Kyriakou A, Nicolaides NC, Skordis N. Current Approach to the Clinical Care of Adolescents With Gender Dysphoria. Acta BioMed (2020) 91(1):165-75. doi: 10.1111/j.1365-2125.2011.04031.x

60. Schagen S, Wouters F, Cohen-Kettenis P, Gooren LJ, Hannema SE. Bone Development in Transgender Adolescents Treated With GnRH Analogues and Subsequent Gender-Affirming Hormones. J Clin Endocrinol Metab (2020) 105(12):e4252-63. doi: 10.1089/lgbt.2016.0190

61. Cohen-Kettenis P, Klink D. Adolescents With Gender Dysphoria. Best Pract Res Clin Endocrinol Metab (2015) 29(3):485-95. doi: 10.1097/AOG. 0000000000000692

62. Abramowitz J. Hormone Therapy in Children and Adolescents. Endocrinol Metab Clin North Am (2019) 48(2):331-9. doi: 10.1007/BF01542220

63. Brik T, Vrouenraets LJJJ, de Vries MC, Hannema SE. Trajectories of Adolescents Treated With Gonadotropin-Releasing Hormone Analogues for Gender Dysphoria. Arch Sex Behav (2020) 49(7):2611-8. doi: 10.1210/jc.2017-01927

64. Martinez C, Rikhi R, Haque T, Fazal A, Kolber M, Hurwitz B, et al. Gender Identity, Hormone Therapy and Cardiovascular Disease Risk. Curr Probl Cardiol (2020) 45(5):100396. doi: 10.1111/and.12660 
65. Aranda G, Fernández-Rebollo E, Pradas-Juni M, Hanzu FA, Kalko SG, Halperin I, et al. Effects of Sex Steroids on the Pattern of Methylation and Expression of the Promoter Region of Estrogen and Androgen Receptors in People With Gender Dysphoria Under Cross-Sex Hormone Treatment. J Steroid Biochem Mol Biol (2017) 172:20-8. doi: 10.1080/15532739.2015.1075931

66. Fernández R, Ramírez K, Gómez-Gil E, Cortés-Cortés J, Mora M, Aranda G, et al. Gender-Affirming Hormone Therapy Modifies the CpG Methylation Pattern of the ESR1 Gene Promoter After Six Months of Treatment in Transmen. J Sex Med (2020) 17:1795-806. doi: 10.1056/NEJMcp1008161

Conflict of Interest: The authors declare that the research was conducted in the absence of any commercial or financial relationships that could be construed as a potential conflict of interest.
Publisher's Note: All claims expressed in this article are solely those of the authors and do not necessarily represent those of their affiliated organizations, or those of the publisher, the editors and the reviewers. Any product that may be evaluated in this article, or claim that may be made by its manufacturer, is not guaranteed or endorsed by the publisher.

Copyright (c) 2021 Aranda, Halperin, Gomez-Gil, Hanzu, Seguí, Guillamon and Mora. This is an open-access article distributed under the terms of the Creative Commons Attribution License (CC BY). The use, distribution or reproduction in other forums is permitted, provided the original author(s) and the copyright owner(s) are credited and that the original publication in this journal is cited, in accordance with accepted academic practice. No use, distribution or reproduction is permitted which does not comply with these terms. 